Mongolian Academy of Sciences
Mongolian Journal of Chemistry
Institute of Chemistry \& Chemical Technology

\title{
Biochemical Study of Mumijo in Uvs province, Mongolia
}

\author{
J. Sukhdolgor ${ }^{1}$, D. Orkhonselenge ${ }^{2}$ \\ ${ }^{1}$ Department of Biochemistry and Bioorganic Chemistry, School of Biology and Biotechnology, National University of \\ Mongolia, Ulaanbaatar 210646, Mongolia \\ ${ }^{2}$ Biotechnology production, Research and Training Center, Public Health Institute, \\ Ulaanbaatar 458645, Mongolia
}

\begin{abstract}
The authors cleared mumijo by extractive and distil methods, defined pure output of natural mumijo and compared difference between these two methods. We defined the amount of dry and extractive substances, raw oil, antioxidant-rutin, vitamin $\mathrm{C}$, fulvic acid, common nitrogen and total protein, content of protein amino acids, and mineral elements in natural mumijo. We exposed 13 protein amino acids in sample of natural mumijo. The content of total irreplaceable amino acids (5) were $26.2 \%$. The authors defined macro and microelements (42) in ash of natural mumijo. In sample of mumijo exposed 10 elements are oxide form, W, Y, Cs, La-rare metal of the earth, and actinoids- Nd, Th, U; lantanoids-Pr, Sm. The same exposed non-ferrous metal-Cu, Mo; light metal$\mathrm{Al}$, mixed metal- $\mathrm{Pb}, \mathrm{Zn}$. However, the valuable metals- $\mathrm{Au}, \mathrm{Ag}$ and white gold are not exposed.
\end{abstract}

Keywords: Mumijo, protein amino acids, fulvic acid, mineral elements

\section{Introduction}

$\mathrm{M}$

umijo, also known as momia and shilajit is a thick, sticky tar-like substance with a colour ranging from white to dark brown, which sometimes found in Caucasus, Altai mountains and Tibet mountain chains. Mumijo is a word of Greece origin. The substance is mentioned in the works of Aristotle and Avicenna as a remedy with antiseptic and general stimulant properties used people in Caucasus. Most scientists agree that people observed wounded animals frequenting caves with mumijo and discovered the substance, similar substances are used for medicinal purposes throughout Tibet (Berun, 10 ${ }^{\text {th }}$ century; Jambaldorj, 1978).

Some scientific research on mumijo has been done in the former USSR, including fullscale clinical trials. Most information on mumijo is known from Russian literature sources.
Mumijo is still unclear whether it has geological or biological origin as it has numerous traces of vitamins and amino acids.

Mumijo is not toxic, at least in reasonable quantities. A mumijo-like substance from Antarctica was found to contain glycerol derivatives and was also believed to have medicinal properties. Mumijo has a wide spectrum of pharmacological activity. A unique plant extract in combination with dozens of minerals: six amino acids, vitamins, $\mathrm{A}, \mathrm{B}, \mathrm{C}$ and $\mathrm{P}$, natural steroids, terpenoids, phospholipids and polyphenol complexes. Mumijo contains trace and micro-elements (cobalt, nickel, copper, zinc, manganese, chromium, iron, sodium, potassium, magnesium, and others) (Shakirov, 1963).

Mongolian researchers were studied about Mumijo at an ancient time. Agvaandondov (1991) translated it as "Khar magic", "Brown method" and "Historical 
ensemble of Mongol khar magic", our high writer of $18^{\text {th }}$ century Lunggregdandar wrote "Jud-shiin habit" work, scientist Ishdanzanvanjil (1868) composed "Jiru-dosil" in Tibetian language. He wrote that mumijo need in prescription of gastric disease. Khaidav (1982) and Ambaga et al., (1989) were had similar explanation. Famous doctor Choijamts (1920) composed about mumijo in his work "Very wonderfully wedding foundation". Later, Danzan (1995) translated this work, Enkh-Oyun (2008) composed thesis "Mumijo preparation influence on bone callus and some indices of patience for cattle and animals".

Fulvic acid, one of two classes of natural acidic organic polymer that can be extracted from humus found in soil, sediment or aquatic environments. This name derives from latin fulvus, indicating its yellow colour.

Fulvic acid (not to be confused with folic acid) is rapidly being recognized as one of the key elements in many outstanding health and scientific breakthroughs of the $21^{\text {st }}$ century. Scientists and doctors throughout the word are beginning to discover fulvic acid and starting to recognize its extraordinary potential. Fulvic acid has always occurred naturally in organic plants and soils. It increases energy, it is a ferocious antioxidant and free radical scavenger, chelates heavy metals and body toxins, removing them from the system (Ponomareva et al.,1969).

\section{Experimental}

Material and methods. Mumijo material was collected from "Yoliin shil" of the Umnogovi sum of the Uvs province in September, 17. 2009. Mumijo sample was purified by extraction and distillation methods (MNS 5725:2007). Dry substance was determined by method of weight stability, the raw oil by method soxhlet, extractive substance by method of Pleshkov, total protein by Kjeldahl method, protein amino acid by paper chromatography, vitamin $\mathrm{C}$ by titration method 2,6dichlorinephenolindophenol sodium, rutin was determined by method of Murri, fulvic acid by vacuum evaporate method.

\section{Results and Discussion}

We cleared natural mumijo by extractive and distil methods (Table 1).

Table 1. Purely output compared by two methods.

\begin{tabular}{|l|c|c|c|c|c|}
\hline $\begin{array}{c}\text { Sample of } \\
\text { mumijo }\end{array}$ & $\begin{array}{c}\text { Purified } \\
\text { method }\end{array}$ & $\begin{array}{c}\text { Extract } \\
\text { of } \\
\text { mumijo }\end{array}$ & $\begin{array}{c}\text { Weigh } \\
\text { t of } \\
\text { extract } \\
(\mathrm{g})\end{array}$ & $\begin{array}{c}\text { Weigh } \\
\text { t of } \\
\text { after } \\
\text { clear } \\
(\mathrm{g})\end{array}$ & $\begin{array}{c}\text { Purel } \\
\mathrm{y} \\
\text { outpu } \\
\mathrm{t}(\%)\end{array}$ \\
\hline $\begin{array}{l}\text { "Yoliin } \\
\text { shil" }\end{array}$ & $\begin{array}{c}\text { Extracti } \\
\text { on }\end{array}$ & natural & 5 & 2.742 & 54.8 \\
\cline { 2 - 6 } $\begin{array}{l}\text { i district } \\
\text { of the } \\
\text { Uvs } \\
\text { province }\end{array}$ & $\begin{array}{c}\text { distillati } \\
\text { on }\end{array}$ & natural & 5 & 1.02 & 20.4 \\
\hline
\end{tabular}

Purely output compared in between two methods: by extractive method was-54.8\%, by distil method was-20.4\%. An extractive method was more effective $(34.4 \%)$ than distilling method. Dry substances of natural mumijo was $95.23 \%$, water $4.77 \%$.

We have determined biochemical components of natural and pure mumijo.

Table 2. Some results of biochemical characteristics of natural and pure mumijo.

\begin{tabular}{|c|c|c|c|c|c|c|c|c|}
\hline $\begin{array}{l}: \stackrel{\circ}{\Xi} \\
\stackrel{\Xi}{\Sigma}\end{array}$ & 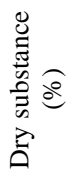 & 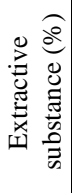 & 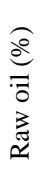 & 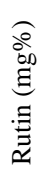 & 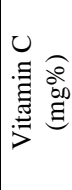 & 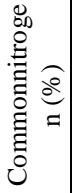 & 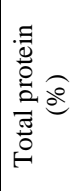 & 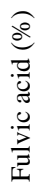 \\
\hline $\begin{array}{l}\widetilde{\pi} \\
\text { 完 } \\
\text { Z }\end{array}$ & $\begin{array}{l}\text { त̂ } \\
\text { }\end{array}$ & 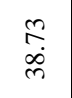 & $\underset{\text { r̦ }}{\tilde{\sigma}}$ & $\stackrel{n}{n}$ & 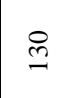 & $\underset{\sim}{\stackrel{J}{\sim}}$ & $\stackrel{\text { İ }}{\dot{I}}$ & 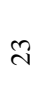 \\
\hline 总 & 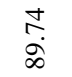 & $\frac{\tilde{d}}{\tilde{d}}$ & $\stackrel{n}{n}$ & $\underset{\sigma}{F}$ & $\bar{\beth}$ & $\stackrel{\mathbb{f}}{=}$ & $\begin{array}{l}\infty \\
\stackrel{0}{0}\end{array}$ & $\mathbb{Z}$ \\
\hline
\end{tabular}

Dry substance of natural mumijo was $95.23 \%$ and of pure mumijo was $89.73 \%$, extractive substance of natural mumijo was $38.73 \%$, but of pure mumijo was $21.05 \%$; raw oil of natural mumijo was $3.02 \%$, of pure mumijo was $2.53 \%$; rutin of natural mumijo was $0.53 \mathrm{mg} \%$ of pure mumijo was $0.41 \mathrm{mg} \%$; antioxidant vitamin $\mathrm{C}$ of natural mumijo was $130 \mathrm{mg} \%$, of pure mumijo was $121 \mathrm{mg} \%$; total protein of natural mumijo was $14 \%$, and total protein was more $(3.2 \%)$ than pure mumijo. The fulvic acid in sample of natural mumijo was $23 \%$. 


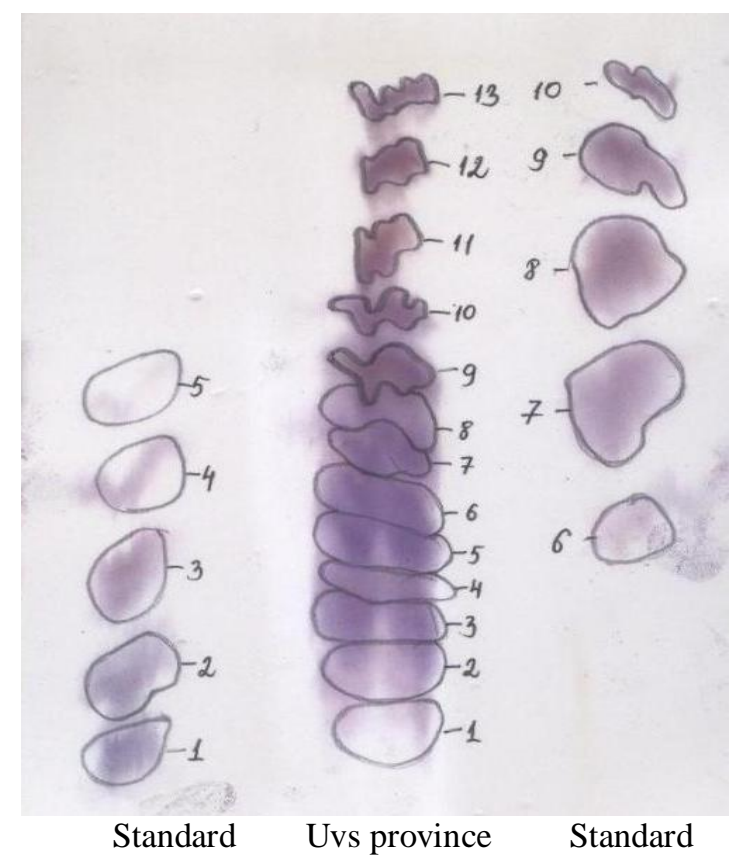

Fig. 1. Chromatogram of experimental and standard amino acids.

Amino acids in natural mumijo have been determined by paper chromatography. (Fig 2).

Fig 2. Content of protein amino acids in natural mumijo (\%)

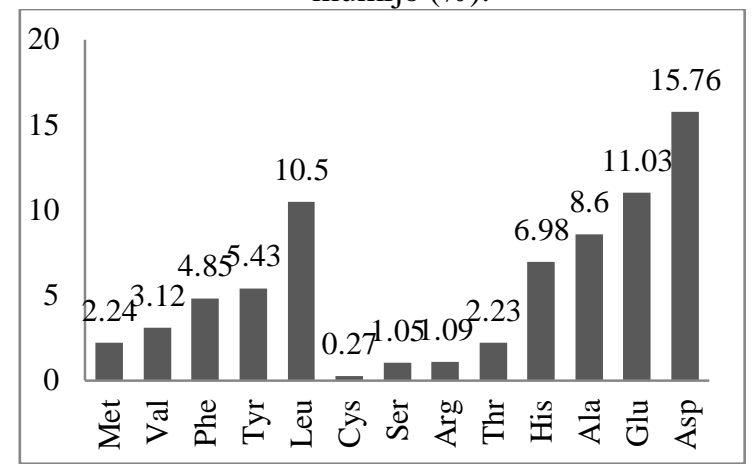

We exposed 13 protein amino acids in sample of dry natural mumijo. The content of essential amino acids (methionine, valine, phenylalanine, tyrosine, and leucine) were $26.2 \%$. The content of replaceable amino acids (cysteine, serine, arginine, threonine, histidine, alanine, glutamic acid, and aspartic acid) were $47.01 \%$. The content of leucine was high $(10.5 \%)$ more than other essential amino acids. Aspartic acid was high in content $(15.76 \%)$ than other replaceable amino acids. Content of cysteine was very little $(0.27 \%)$ than other amino acids.

We have defined content of mineral elements in ash of natural mumijo, where exposed 42 mineral elements. Most elements measured in ppm. But, we calculated it in percentage. In sample of natural mumijo exposed 10 elements were oxide form.

Table 3. Amount of mineral elements in ash of natural mumijo (\%).

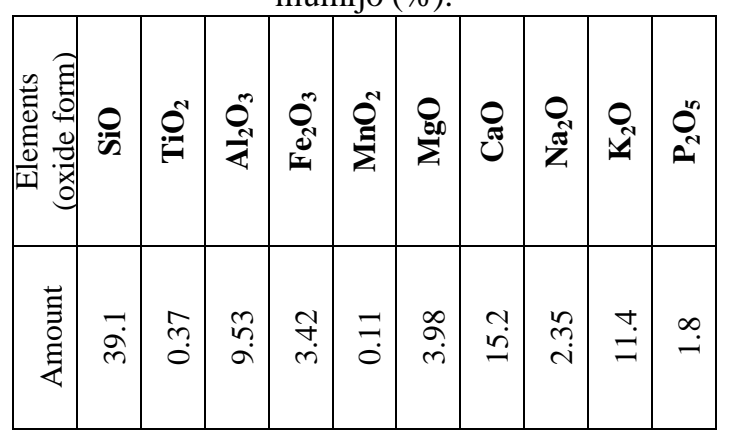

\begin{tabular}{|c|c|c|c|c|c|c|c|c|c|}
\hline 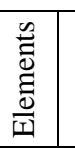 & $\frac{n}{4}$ & $\mathscr{0}$ & $\bar{\theta}$ & تُ & 8 & ש & u & $\tilde{J}$ & Ðే \\
\hline 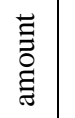 & $\overrightarrow{\bar{\delta}}$ & $\begin{array}{l}\stackrel{0}{0} \\
\text { فิ } \\
\stackrel{0}{0}\end{array}$ & $\begin{array}{l}\text { oे } \\
8 \\
0 \\
0\end{array}$ & $\begin{array}{l}\overline{0} \\
0 \\
0\end{array}$ & $\begin{array}{l}2 \\
\delta \\
0 \\
0\end{array}$ & $\stackrel{\infty}{\stackrel{\infty}{8}}$ & $\begin{array}{l}\check{\delta} \\
\stackrel{\delta}{0} \\
\stackrel{0}{0}\end{array}$ & ڤิ & oे \\
\hline 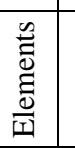 & $\Xi$ & $\stackrel{\Im}{9}$ & $\stackrel{\theta}{\Sigma}$ & $\hat{\mathbf{z}}$ & $\bar{z}$ & $\ddot{z}$ & $\hat{a}$ & 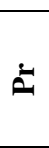 & $\hat{\not{\Omega}}$ \\
\hline $\begin{array}{l}\text { 訔 } \\
\text { 音 }\end{array}$ & 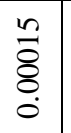 & 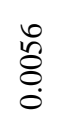 & $\begin{array}{l}n \\
\delta \\
0 \\
0\end{array}$ & 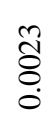 & $\begin{array}{l}n \\
\hat{8} \\
0 \\
0\end{array}$ & $\begin{array}{l}0 \\
\stackrel{0}{0} \\
0 \\
0\end{array}$ & $\begin{array}{l}0 \\
8 \\
8 \\
0\end{array}$ & ôे & $\stackrel{n}{a}$ \\
\hline 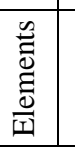 & $\hat{n}$ & $\ddot{n}$ & हี & ตี & $\dot{\Delta}$ & $\approx$ & $E$ & 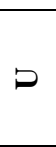 & $\lambda$ \\
\hline 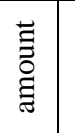 & $\begin{array}{l} \pm \\
8 \\
0 \\
\dot{0}\end{array}$ & $\bar{\delta}$ & $\stackrel{8}{0}$ & 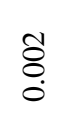 & $\begin{array}{l}0 \\
\tilde{n} \\
0 \\
0\end{array}$ & $\begin{array}{l}8 \\
\vdots \\
0 \\
0\end{array}$ & $\begin{array}{l}\bar{\delta} \\
\dot{\delta} \\
0\end{array}$ & 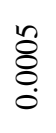 & $\frac{1}{8}$ \\
\hline 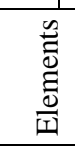 & & 3 & & $\lambda$ & งี & & $\dot{\mathbf{N}}$ & & 5 \\
\hline $\begin{array}{l}\text { 志 } \\
\text { 蒠 }\end{array}$ & & $\begin{array}{l}\widehat{\delta} \\
\stackrel{\delta}{0} \\
\stackrel{0}{0}\end{array}$ & & ¿ & $\begin{array}{l}\text { ¿ै } \\
\text { ठ } \\
0\end{array}$ & & $\frac{\mathrm{d}}{\mathrm{d}}$ & & 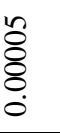 \\
\hline
\end{tabular}

The amount of silicon oxide was very high (39.1\%) than other mineral oxide form. The calcium oxide was $15.2 \%$ etc. The nonferrous metals, $\mathrm{Cu} 0.0037 \%$, Mo $0.0005 \%$; light metal $\mathrm{Al}$ 9.53\%; mixed metal, $\mathrm{Pb}$ $0.0016 \%, \mathrm{Zn} 0.0126 \%$. The rare metal $\mathrm{W}$ was $0.0027 \%$, Y-0.0061\%, Cs- $0.0025 \%$, La$0.0056 \%$.

\section{Conclusions}

- Purely output of natural mumijo, as compared between two used methods revealed that the extractive method was more effective than distil method. 
- Dry substances of natural mumijo was 95.23\%. The extractive substance of natural mumijo was $38.73 \%$, and in pure mumijo it was $21.05 \%$. The raw oil of natural mumijo was $3.02 \%$, and in sample of pure mumijo it was $2.53 \%$. Antioxidant vitamin $\mathrm{C}$ and rutin of natural mumijo were $130 \mathrm{mg} \%, 0.53 \mathrm{mg} \%$. The contents of latter were equal in sample of pure mumijo $121 \mathrm{mg} \%, 0.41 \mathrm{mg} \%$. In the sample of natural and pure mumijo we defined total protein. The fulvic acid in sample of natural mumijo was $23 \%$.

- The content of essential amino acids were 5 , replaceable amino acids were 8.

- In ash of natural mumijo, we defined 42 mineral elements, of which 10 elements were in oxide form. In ash of natural mumijo exposed some rare metals, nonferrous metals, light metals, mixed metals, actinoids and lantanoids.

\section{Acknowledgement}

We performed this research with support of the Mongolian Foundation for Science and Technology at the Spectrum laboratory of the Central Geological Laboratory.

\section{References}

1. Agvaandondov Sh. 1991. "Historical Ensemble of Mongol Khar magic" Ulaanbaatar, Mongolia. p.10

2. Ambaga M, Tuya B. 1989. Some study of medicinal plant used for public medicine. Ulaanbaatar, Mongolia. p.10-13

3. Enkh-Oyun T. 2008. "Mumijo preparation influence on bone callus and some indices of patience for cattle and animals". Thesis. Ulaanbaatar, Mongolia. p.6-14

4. Jambaldorj A. 1978. A study of Mongol medicine. Ulaanbaatar p.5456

5. Khaidav Ts. 1982. Animal origin drug used for public medicine. Ulaanbaatar, Mongolia. p.104-105

6. Ponomareva, V.V., \& Ragim-Zade, A.I. 1969. Comparative study of fulvic and humic acids as agents of silicate mineral decomposition. Society Soil Science, 1, 157-165. (Trans. From Pochvovedenic. (1969), 3, 26-36)

7. Shakirov A.Sh. 1963. Mumijo and its significance in public medicine. Tashkent. p.56-58 